\title{
Implementation of Human Rights Protection Towards in Penitentiary of Children in Makassar \\ Mursyid Mursyid
}

\author{
Faculty of Law, Universitas Muslim Indonesia
}

email: mursyid.mursyid@umi.ac.id

\begin{abstract}
The urgency of child protection encourages a variety of efforts carried out by the government and society because it is considered not only to protect children as human beings but also as part of national development. Crimes or violations committed by the child then serve the sentence set by the juvenile justice process should still get full protection because it is considered the child still has a long future and the opportunity to build a nation after undergoing accountability errors that make it a human hope for the future come. The purpose of the study is to analyze the implementation of protection of human rights and the factors that influence the implementation of human rights protection for children in the Makassar Correctional Institution. As a result, the implementation of human rights against child prisoners is still less effective, because conceptually and in reality there has not yet been a clear difference between the implementation of human rights for adult prisoners. This study shows that there is no specific pattern that is applied in implementing human rights to children, where the practice of implementing child prisoner formation is still not in accordance with the basic idea, namely providing protection in order to achieve child welfare. The factors are legislation, facilities and infrastructure, organizational structure, human resources and administrative management, and not yet integrated handling of the implementation of human rights for child inmates by the entire criminal justice system.
\end{abstract}

Keywords : Human Rights Protection; Prisoner; Children; Penitentiary;

\section{INTRODUCTION}

Problems and efforts to protect children seem to never stop being discussed, because it is our duty together to always seek various efforts in order to provide protection for children in all fields. Child protection as the nation's successor is a field of national development, ${ }^{1}$ because protecting children means protecting humans and building whole people,$^{2}$ therefore the protection of children is also aimed at children who experience behavioral problems (violations of young age), because the child who commits a crime is not because he has an evil nature, but because the child's condition is unstable due to circumstances that come from the child himself or from the outside, namely the environment surrounding it. $^{3}$

${ }^{1}$ Febriana, A. (2017). Penegakkan Hukum terhadap Anak yang Melakukan Tindak Pidana Pencabulan dalam Konsep Restorative Justice. ADIL: Jurnal Hukum, Universitas YARSI, 7(2), p. 203. 15.

2Pramukti, A. S., \& Primaharsya, F. (2018). Sistem Peradilan Pidana Anak. Yogyakarta: Media Pressindo, p.

3/bid., p. 18. 
Another important consideration to be observed is for the growth and mental development of children in their growth towards adulthood, on the basis of these needs, it is deemed necessary to determine the difference in treatment under procedural law and its criminal threat. Setting exceptions and provisions stipulated in Law No. 8 of 1981 concerning the Criminal Procedure Code, the old implementation of detention is determined in accordance with the interests of the child and the differentiation of the threat of punishment for children is determined by Law No. 5 of 1998, Law No. 39 of 1999, Law No. 35 of 2014 concerning Amendments to Law No. 23 of 2002 concerning Child Protection and Law Number 11 of 2012 concerning the Criminal Justice System for Children whose criminal imprisonment is determined (one half) of the maximum, the threat of capital punishment and life imprisonment is not applied to children. Differences in treatment and threats stipulated in the Act above are intended to better protect and protect the child so that he can support his long future. In addition, this distinction is intended to provide an opportunity for children so that through guidance they will get their identity to become human beings who are independent, responsible, and useful for themselves, their families, communities, nations and countries ${ }^{4}$ Judge's decision will affect the next life of the child concerned, ${ }^{5}$ Therefore the Judge must be sure that the decision will be a strong basis for returning and regulating children towards a good future to develop themselves as citizens who are responsible for family life, nation and state. To further strengthen efforts to guide and provide guidance for children who have been decided by the Judge, the child will be accommodated in the Child Correctional Institution. Various considerations through thoughts and rules are contained as well as in order to realize a judiciary that pays attention to the protection and interests of the child as aspired, ${ }^{6}$ then it is necessary to regulate the provisions regarding the implementation of a court specifically for children in the General Court environment, thus the effectiveness of the Juvenile Court is expected to provide appropriate direction in fostering and protecting children. ${ }^{7}$

The description of the phenomena concerning the rights of child prisoners which until now has not been fully implemented ${ }^{8}$ which must be considered and given protection, especially child development that is very sensitive to the surrounding environment. So according to this article, it is considered necessary to describe various descriptions of how

\footnotetext{
${ }^{4}$ Wahyudi, S. (2009). Penegakan Peradilan Pidana Anak dengan Pendekatan Hukum Progresif dalam Rangka Perlindungan Anak. Jurnal Dinamika Hukum, Universitas Jenderal Soedirman, 9(1), p. 29.

${ }^{5}$ Febriana, A. (2017). Op. Cit., p. 207.

${ }^{6}$ Dwiatmodjo, H. (2011). Pelaksanaan Perlindungan Hukum terhadap Anak yang Menjadi Korban Tindak Pidana di Wilayah Hukum Pengadilan Negeri Banyumas. Jurnal Dinamika Hukum, Universitas Jenderal Soedirman, 11(2), p. 203.

${ }^{7}$ Hilman, D. P., \& Indrawati, E. S. (2018). Pengalaman Menjadi Narapidana Remaja di Lapas Klas I Semarang. Empati, Universitas Diponegoro, 6(3), p. 197.

${ }^{8}$ Other writings also describe the concrete facts of the urgency of protecting children's rights. Vide: Munandar S. (2018). Pelaksanaan Perlindungan Hukum terhadap Hak Anak yang Berkonflik dengan Hukum pada Tahap Penyidikan dalam Sistem Peradilan Pidana Anak (Studi di Wilayah Hukum Polresta Padang). Pagaruyuang Law Journal, Universitas Muhammadiyah Sumatera Barat, 2(1), pp. 58 - 59.
} 
to protect human rights at the Makassar Correctional Institution, especially for children placed in Adult Prisons, namely the Makassar Class 1A Correctional Institution. Based on the background stated, the problem statement can be identified are: 1 . What is the implementation of human rights protection for children at the Makassar Correctional Institution ?, 2. What factors influence the implementation of human rights protection for children at the Makassar Correctional Institution?

\section{ANALYSIS AND DISCUSSION}

\section{A. Human rights on Children Prisoner in Child Penitentiary of Makassar}

The length of the criminal period is important to know in relation to the rights of prisoners to obtain their rights including assimilation and remission, that most child prisoners get a sentence of imprisonment for one year and under or short-term criminal punishment. This short-term criminal offense certainly has an influence on the child prisoner formation program. As stated in UN resolution 40/33 (Beijing Rules), in section III, that deprivation of independence for children is only possible as a last resort, and even then only for a minimum period of time, and for certain cases only.

In addition, this international trend can be seen in the United Nations Congresses, requiring the limitation of the possibility of a short jail term, because besides bringing negative adverse effects, it is also less supportive of the correctional guidance system and not in accordance with the Minimum Standards of the Rules. This does not mean that short imprisonment is abolished, but this crime is still needed in certain cases, namely only the use is limited. Therefore the statement of this Resolution must be followed up, that is what about children who have been sentenced to short prison terms, what is the next step so that short prison terms do not have a negative effect on child prisoners, for example incitement from criminal offenders higher class both physically and psychologically, this is because children are very sensitive to changes in the surrounding environment. In addition, it is feared to cause social stigma (children's image) which has a negative impact on children's development, ${ }^{9}$ because after all imprisonment is a very heavy thing for children. Therefore, it needs a very careful attitude in placing children in the institution for the future development of the child, do not let the correctional institution as a sub-system of criminal justice and as a place to implement imprisonment into a place as stated by Andenaes as a "ceremony of degradation" (degradation ceremony), and ignore the principles of child protection. ${ }^{10}$

${ }^{9}$ Related to the image of children in their social environment is also worrying. Vide: Aswari, A., Buana, A. P., \& Rezah, F. S. (2018). Harmonisasi Hukum Hak untuk Dilupakan bagi Koran Digital terhadap Calon Mahasiswa di Makassar. Kanun: Jurnal IImu Hukum, Universitas Syiah Kuala, 20(1), p. 44.

${ }^{10}$ Pulunggono, W., \& Chalim, M. A. (2017). Kebijakan Perlindungan Hukum terhadap Anak Korban Kekerasan dalam Rumah Tangga dengan Kontribusi Upaya Pembaharuan Hukum Pidana Nasional. Jurnal Hukum Khaira Ummah, Universitas Islam Sultan Agung, 12(2), p. 342. 
Besides that, children who really have to enter the institution are sought so that the training carried out is not just about filling time. Education and work provided must be able to lead to "self respect" in children in order to prepare themselves back into society. If it is possible specifically for children who receive short prison terms there are exceptions to the correctional stages that apply to child prisoners. they do not absolutely follow the correctional stages with the requirements of the time determined by the correctional system, because if they follow the procedures of the stages, the main goal of correctional treatment will not be achieved if we look at the basic idea of formation that tends to divide - for the life of the prisoner based on time (time sentence), starting from $1 / 3,1 / 2$ to $2 / 3$ of the criminal period he lives in.

By basing absolutely on the time limit, problems will arise, for example there are times when inmates have reached the limit that time, but in $w$ then the child has not behaved in a manner that meets the specified requirements, in the sense that the child has not shown an increase in behavioral improvement. And the most dangerous thing is if the prisoners have passed this period of time, but because of the many procedures that must be taken to obtain wider rights, then a shortcut is taken, that is, those who have passed the deadline are given rights more broadly without any consideration of their behavior. Conversely on the other hand there are some cases that prisoners who have not taken the time limit specified in the stages of the correctional process have shown good behavior, but because they are fixated on the time rules set in the correctional process, eventually they have to wait long to get the right broader rights.

Balancing efforts should be taken in the middle way, which is not absolutely fixed on the specified time stages in the correctional process, so that the implementation can be flexible, by looking at the condition of each child. It is better to follow a credit point system for every good behavior and achievement carried out by child prisoners, so that this system is used as a basis for children to obtain wider rights in their coaching process, often remembering that the child inmate has only committed a crime for the first time. thus they are first offender. It is better for us to look again at Article 45 of the Criminal Code, even though with the birth of the Juvenile Court Law, this Article is declared invalid, but as an illustration it will appear, that the article in the Criminal Code especially in this section is more protective for children.

In this article it states: "... and has not passed two years since it was declared wrong because of the violation or crime mentioned above..." from this article it can be interpreted that a child who has for the first time committed a crime should be indirect sentenced to imprisonment that they must undergo in a penitentiary. In the Juvenile Court Law it is not regulated on this matter.

Observation data of child inmates based on the age group of 60 children, those under the age of 12 were not found in the Makassar Correctional Institution, and those 
aged $12-15$ years were 20 people or $33,3 \%$, and those aged between $15-18$ year totaling 33 people or $55 \%$ and those over the age of 18 numbered 7 people or $11.7 \%$. This age group is important to know to determine a coaching program that must be run in a prison. Observation of Article 20 of Law Number 12 Year 1995 concerning Corrections, stated that: In the framework of fostering child prisoners in Correctional Institutions, classification is carried out based on:

a. Age;

b. Gender;

c. Duration of sentence imposed;

d. Type of crime;

e. Other criteria according to the needs or development of coaching.

Furthermore, this classification is further regulated by a Ministerial Decree. In the explanation of the law it does not provide a clear description of the basic concept of the classification. And the Ministerial Decree in question also does not yet exist. And in its implementation at the Makassar Correctional Institution conceptually and practically in the classification program only on sex and even then it is only done by block / room separation, because Makassar does not have a special juvenile correctional institution. The concept of safe protection in its application there are some child inmates who are still at the institution who are feared to have a negative impact both physically and psychologically on inmates of younger children. ${ }^{11}$ Whereas according to Law Number 11 of 2012 concerning the Juvenile Court System in Article 60 said; that correctional students are placed in a juvenile correctional institution that must be separated from adults. Article 61 states that a criminal child who has not finished his sentence and has reached the age of 18 must be immediately transferred. If it is not yet 21 years old, it is placed in a Young Adult correctional institution, but this study shows that classification based on the type of crime and recidivism is also not done at this institution. According to the Binakdik section, this classification is not done so that they can "mingle" with other child inmates, but unfortunately this is a false understanding, because based on national and international legislation the concept of community with other fellow inmates is not the case. The condition of handling children in the land is very concerning and deserves caution because those who have repeatedly committed crimes if they are not separated from those who are beginners, are worried that they will transmit negative traits. ${ }^{12}$

There are a number of factors why 18-year-old inmates are still placed in juvenile correctional facilities. One of them is at the time of the trial the child claimed to

${ }^{11}$ Toha, S. (2009). Aspek Hukum Perlindungan terhadap Anak. Jakarta: Pusat Penelitian dan Pengembangan Hukum, Badan Pembinaan Hukum Nasional. Departemen Hukum dan HAM RI, p. 94.

${ }^{12}$ Jafar, K. (2015). Restorative Justice atas Diversi dalam Penanganan Juvenile Deliquency (Anak Berkonflik Hukum). Al-'Adl, Institut Agama Islam Negeri Kendari, 8(2), p. 83. 
be under 18 years old, because he did not have a birth certificate, so of course the judge decided based on the consideration that the child was under the age of 18 , so that if the verdict was imprisoned child correctional institution. Not heeding the placement of prisoners based on age, this shows the inconsistency in national legislation as well as international instruments which confirms the need for placement of prisoners based on age classification to determine the next coaching program. Another factor that causes more 18-year-old inmates to remain in juvenile correctional institutions is the problem of procedures for transferring prisoners who must be taken. As stated in the Pattern of Guiding Prisoners and Students in 1990, this transfer is permitted on the following grounds: (a). Coaching; (b). Security. ${ }^{13}$

Various information obtained from observations about the status of children before they enter the correctional institutions, so most of them are school dropouts and workers, most of whom drop out of school live on the streets. Meanwhile, based on the motivation to commit a crime, it is partly due to economic pressure and because of the influence of friends or the environment where the children interact. Based on this, it can be determined what the next coaching program is for them. There were a number of children who were unable to attend school because they had to be required to enter school before entering the correctional institution. The existence of a statement that they had attended school was difficult to obtain because in general they had also left school for some time and they were from outside the Makassar City area that had migrated to the city. And to ask their families to take care of it, in general they are embarrassed, there are even families who are not told that they are in a correctional institution because people who have served their sentences in the past can reduce the sense of independence of the person they reported, ${ }^{14}$ besides the economic conditions that do not allow to go back to Lapas Makassar. Although they initially were school dropouts or workers in general they wanted to go to school like children in general. And remembering the criminal given to them is mostly short-term (under one year) criminal so that if you have to wait for a certificate to have attended school from the school concerned it is feared that it will take a long time, while the criminal period has been partially undertaken. How the program will run while for one level of school alone takes one year. Thus a fast motion is needed to simplify this procedure. Or other alternatives for those who have only been sentenced to short prison terms for example 6 months and below are given only skills training and then given a certificate so that it might be useful for those who have left or finished serving a sentence.

${ }^{13}$ Safety and Breach Commission in the American Prison Report, that a serious problem in American prisons is to place child custody in adult prisons, which results in small children being beaten frequently. Vide: Ibid.

${ }^{14}$ Aswari, A., Buana, A. P., \& Rezah, F. S. (2018). Loc. Cit. 
The implementation of worship as a change in lifestyle in prison basically mostly felt that religious guidance in the development of religious aspects within the institution was considered quite good. This religious formation is important, because it is hoped that with this mental formation the child prisoners can be strengthened by their faith and given an understanding to be able to realize the consequences of their actions. A humanistic approach through religious formation must be able to raise the awareness of the violator of human values and the values of social life in society. ${ }^{15}$

Regarding the implementation of worship outside the institution, most of the child inmates basically felt they did not get the right to carry out worship together with the community. Even though this is very important in the context of assimilation and integration with the community. Implementation of worship outside of correctional institutions is important so that child prisoners feel accepted as part of the community. It is better for prisoners to be included, for example in lightning pesantren joining children in general, of course with supervision by officers. Thus there are two benefits at once, namely in addition to increasing the thickness of faith, also child inmates are trained to adapt to children in general. Regarding physical and spiritual care, basically some feel less. The care of child inmates does not work as it should, which serves to keep them physically and mentally healthy, so that they must continue to obtain sufficient needs, such as food, water for drinking and bathing, but it is very unfortunate because of limited facilities and the capacity is not in line with the expectations of the implementation of protection for child prisoners in Indonesia. ${ }^{16}$ Especially for food, food must be considered with a number of calories that is suitable for the growth of children. In addition, what must be considered is how to give food to child prisoners not to lower their dignity as humans.

Regarding health services, some child prisoners feel they are not getting it, this is probably due to the number of medical personnel (general practitioners) who are only two people in prison. Whereas for those who feel they are getting enough health care, those who are affected by minor illness, most of the diseases suffered by child prisoners are skin diseases, metabolic disorders, difficulty sleeping, this is due to poorly maintained sanitation or hygiene, and the nutrition they obtain from food. In the event the health check is carried out if there is a request from the prisoner in question. Health checks should be carried out routinely every month, with preventive health services and curative services so that it is expected that the conditions of child

${ }^{15}$ Rambitan, C. M. (2013). Tugas dan Fungsi Lembaga Pemasyarakatan dalam Merehabilitasi Anak yang Sedang Menjalani Hukuman. Lex et Societatis, Universitas Sam Ratulangi, 1(3), p. 75.

${ }^{16}$ Rumadan, I. (2013). Problem Lembaga Pemasyarakatan di Indonesia dan Reorientasi Tujuan Pemidanaan. Jurnal Hukum dan Peradilan, Mahkamah Agung RI, 2(2), p. 265. 
prisoners are controlled. ${ }^{17}$ And thus health services which are children's rights can be given properly, this is also in accordance with international instruments that health services which include prevention and treatment and mental health must be available in prisons, and better if the health service facilities are also open to the community generally around the location of prisons, this is done to prevent stigmatization of the child while at the same time creating a sense of self-esteem in the child in the context of the child integrating into the community. As for the right to submit complaints, most of them have never submitted complaints, this is because they even though they understand their rights sometimes feel afraid of the officers. Whereas regarding the rights themselves, they have been given at the time of entry orientation and by the institution's staff, each room has been affixed.

Regarding the right to obtain information, some inmates feel good (satisfied) to get it either through reading material or other mass media such as television. This is because the facilities available in correctional institutions, especially regarding reading materials, are sufficient and through 7 television broadcasts they are considered adequate. Regarding the right to receive family visits, some prisoners have never been visited by their families because their families are far from the correctional facilities. For example, Sengkang, Pinrang, Sidrap and the social economic conditions of their parents who are classified as weak so that a visit to a prison requires a large fee. Whereas those who are sometimes visited by their families are those whose families live around the city of Makassar, so that at least they get a visit once a month or once every two months, and those who are frequently visited by their families are because their parents live near or around the area of the institution. Correctional Services of Makassar City. Even though the child has the right to get a visit from his family and close friends and he has the right to make correspondence with his family, because this is one way to ensure that the child can stay in touch with the community outside the institution. In this case the role of the family or parents is very influential on the formation of children in prisons. As stated in the Beijing Rules which states that parents, families are allowed to intervene in efforts to foster children in the institution (Rule 26). Therefore it is necessary to think of an effort to transfer children to correctional facilities for children who are at least close to their families. In this case, of course, by simplifying the procedure for transferring child inmates.

Another problem that arises is about the length of time to visit, between one inmate with another inmate is not the same, this raises jealousy between prisoners with one another. Therefore there needs to be a regulation about the length of time to visit, and the firmness of the officer regarding the length of time to visit. This is

${ }^{17}$ Sanusi, A. (2016). Aspek Layanan Kesehatan Bagi Warga Binaan Pemasyarakatan dan Tahanan di Lembaga Pemasyarakatan dan Rumah Tahanan Negara (Aspects of Health Carestowards Convicts and Inmates). Jurnal IImiah Kebijakan Hukum, Badan Penelitian dan Pengembangan Hukum dan HAM, 10(1), p. 42. 
important so as not to cause negative effects between one inmate and another inmate. Furthermore, to find out the rights of child prisoners to obtain remission, it must also be known about the length of the criminal sentence, this is related to the requirements regarding remission. ${ }^{18}$

When looking at the length of the criminal period, those who have the right to receive remission are prisoners who are serving a sentence of more than six months, thus based on 60 child prisoners formally 9 people who are entitled to remission are 51 while those who are not entitled to remission are 51. The implementation of remission is given if during criminal proceedings, child inmates are well behaved, and the reduction in the period of serving this criminal sentence can be increased if during the criminal procedure the prisoner is doing service to the state and carrying out actions that are beneficial for the state and humanity. The reduction in the criminal period is given by the Minister of Justice, which is submitted by the Head of the Correctional Institution in question through the Head of the Regional Office of the Ministry of Justice concerned. Whereas the implementation of remissions at the Makassar Correctional Institution has basically been carried out but because of the many procedures that must be taken so as to cause delays, while their criminal period is sometimes exhausted so that they do not get their rights to obtain remission.

Even though in Article 4 paragraph (1) Implementation of the Presidential Decree of the Republic of Indonesia Number: 174 Year 1999 concerning Remission, it is stated that only Prisoners and Criminal Children have undergone a sentence of 6 (six) to 12 (twelve) months who have received remission. However, this provision also cannot reach the problems that exist in Makassar correctional institutions, because most of them are sentenced to short prison terms, one year down. In this case the role of the Community Observation Team and the Penitentiary Advisory Board needs to be improved so that a rapid movement occurs in dealing with the remission problem of child prisoners, so as soon as possible after observing child inmates. Furthermore, regarding the right of prisoners to obtain assimilation, in this case it must also be known about the criminal period that has been carried out by inmates, this is related to the conditions that must be taken to obtain assimilation permits. For assimilation ${ }^{19}$ given to prisoners who have served half their sentence, while those who have carried out $2 / 3$ of their prison periods are assimilated by providing independent activities outside the prison.

This paper illustrates that formally the prisoners who are entitled to assimilation are 7 people. However, in its implementation, this was not fully done because of

${ }^{18}$ Abdullah, R. H. (2015). Urgensi Penggolongan Narapidana dalam Lembaga Pemasyarakatan. Fiat Justisia: Jurnal IImu Hukum, Universitas Lampung, 9(1), p. 53.

${ }^{19}$ Nugroho, O. C. (2015). Pemenuhan Hak atas Kebutuhan Seksual Warga Binaan Pemasyarakatan. Jurnal HAM, Badan Penelitian dan Pengembangan Hukum dan HAM, 6(2), p. 132. 
procedures involving many parties, which resulted in delays which in the end the prisoners did not obtain full rights in obtaining assimilation. To get assimilation, prisoners must go through a Correctional Observation Team, by listening to the Community Research Report, after holding a hearing and then being proposed to the Head of the Regional Office of the Ministry of Justice, then issuing a decree stating that the person can carry out the assimilation process inside and outside the prison. The problem that is then faced is the number of supervisors who are responsible for prisoners who are undergoing assimilation, especially for those who carry out assimilation with third parties both government and private institutions so that assimilation is carried out mostly in prison only.

Officers who supervise prisoners who are undergoing assimilation outside of prison are all KPLP (Lapas Pengawasan Persatuan Unit) officers and Bimker (Job Guidance) officers. In addition, the role of Judge Wasmat in this matter must be put forward, considering that Judge Wasmat's role has been less effective, because Judge Wasmat's visit was only a formality, namely checking whether the verdict on the prisoner had been carried out. The giving of remission and assimilation should not be based on giving relief or gifts because of good behavior but rather a program as a means of fostering in the correctional process. Thus too complex juridical and administrative requirements need to be reviewed.

Furthermore, regarding the right to obtain parole according to Law 12 of 1995 concerning Correctional Childhood, it is given to prisoners who have served their prison term $2 / 3$ of their imprisonment period of at least 9 months. One of the requirements that must be taken to obtain parole is the existence of a community research report from BAPAS, about families that will accept inmates, the circumstances of the surrounding community and other parties related to child prisoners. Furthermore, community research, which is one of its functions, is to provide a report to the Correctional Observation Team as a material consideration for giving parole. Furthermore, the opinion of child inmates regarding the guidance carried out in the children, there are those who argue that it is more a form of retaliation and some are more coaching, or some inmates who consider the implementation of coaching in institutions, are still tending to retaliation. This should not happen because since the issuance of the Correctional Law and the Juvenile Court Law the orientation of prisoner formation must be changed to a more humane direction.

Criminal decisions in the form of restrictions on freedom must not exceed the mistakes made by the child and must not ignore the sense of justice of the community. ${ }^{20}$ Only what needs to be remembered here for children must be seen proportionally in the

${ }^{20}$ Achmad, R. (2017). Hakekat Keberadaan Sanksi Pidana dan Pemidanaan dalam Sistem Hukum Pidana Legalitas: Jurnal Hukum, Universitas Batanghari, 5(2), p. 93. 
sense that coaching must be seen on a case by case basis. And all child development activities must be based on the basic idea of child protection, and coaching in correctional institutions must still try to change the "naughty nature of children" so that they can be good people, and the community is protected by the inclusion of children in prisons. Guidance for child prisoners who are based on the assumption that imprisonment is retaliation is feared to bring a variety of consequences that harm the child, for example the occurrence of torture in the form of speech, care and placement. Crimes carried out in prisons must be adjusted to the characteristics of the perpetrator.

\section{B. Analysis Factors Influence Human Rights Implementation for Children on Child Penitentiary}

Guidance in the Child Correctional Institution has several factors that need attention because it can function as a supporting factor and can also be a limiting factor. These factors include the following: The pattern and layout of the building as stipulated in the Decree of the Minister of Justice of the Republic of Indonesia No. M.O1. PL.01.01 In 1985 on April 11, 1985 concerning the Building Pattern of Penitentiary Institutions and State Detention Houses, it was necessary to realize this, because the pattern and layout of buildings were important factors to support the implementation of human rights for child prisoners with guidance in accordance with their objectives. correctional service.

Some of the factors that influence the location of the Makassar Penitentiary are:

a. Conditions and Layout of Makassar Correctional

Buildings Location This building is located on the outskirts of the city. In terms of transportation and communication there are no problems. However, because of this Makassar Correctional Institution, the residents are not only from the surrounding area, but can also be from various parts of Indonesia, so that it is certainly difficult for families who will visit their children. At present the state of spatial planning in the Makassar Penitentiary, especially the living space, is well-maintained and takes into account the human dignity and rights of children as human beings so that their basic needs are guaranteed. And correctional institutions have been designed while paying attention to privacy children's and supporting the rehabilitation and integration of children into the community.

b. Facilities needed by Makassar Correctional Institutions

There are a number of facilities that have an influence on the implementation of fostering child inmates, namely;

1. Administration room, which is where all administrative process activities are carried out. Makassar Correctional Institutions have one administrative room that is quite adequate. 
2. Reception room, which is the place for receiving admissions for newly arrived inmates in prisons. Prisoners of newly arrived children are registered and given uniform clothing, which is then put into an orientation cell for some time to determine the next coaching program. This reception room is equipped with facilities for administrative purposes such as registration, shooting, finger marks and matters relating to the reception process. At the Makassar Penitentiary there is also a reception room for newly arrived inmates.

3. Living Room for Child Prisoners

In the living room with medium standard security is subject still to supervision but not too tight. The equipment in this living room is the same as the equipment in the living room with maximum security, namely beds, small tables, cabinets, lighting. In the living room maximum security is still needed due to tight supervision because inmates are considered dangerous.

Regarding the living space of child inmates basically they are still between medium security and maximum security, because supervision is still carried out strictly and the room key is still held by the officer. Indeed the classification of institutions with maximum security, medium security and minimum security is not in accordance with the needs of the prison system. The basis of this classification is only viewed from the security approach, as stated in Article 13 of the Criminal Code and Article 49-56 Gestichten Regulations. It is better to think about the condition of open prison buildings with minimum security standards or the need for semi-institutional facilities that are well coordinated within the framework of integrating children into the community. Although this certainly requires careful planning and preparation which also requires the involvement of an independent institution and is supported by qualified officers.

4. The dining room, all prisoners eat in their cell rooms because the agency officers deliver the food directly. In this case the child has the right to get quality food and sufficient quantity that is adjusted to the growth and development of children and in accordance with health standards.

5. Discipline cells, namely cells to place inmates who violate the rules or discipline of the rules that have been determined. Lapas Makassar has disciplined cells which are intended for child prisoners who violate the regulations. However, this discipline cell is not used because if there is a violation, it will be subject to sanction of reprimand, except for heavy violations.

6. Cell Orientation, which is to place new prisoners as a temporary residence, where they are studied here to determine the next program. Makassar Correctional Institution has one orientation room, this cell is in accordance with its function in giving rights to child prisoners. 
7. Visiting Room, which is the place for holding meetings with families. The Makassar Correctional Institution has a visiting room that is united with the formation administration room. It's just that in its implementation for current family visits even though it has a clear time limit, but sometimes violations still occur. Usually it occurs in prisoners with high social status and also for visitors who are familiar with the officer, the period can be extended.

8. Coaching room, in the framework of fostering prisoners. Then we need rooms that function to support the realization of the coaching.

9. Middle School Study Room (Pursue Package B)

In accommodating educational and scientific activities, under the leadership of the Regional Office of the Ministry of Education and Culture. The problem here is that not all child inmates can attend school here, because they have to take requirements, one of which is a letter information that they attended school before entering the penitentiary.

10. The Work Room (Workshop)

In Makassar Lapas currently has a workspace, which functions as a space for non-formal education. This room serves to carry out skills exercises such as painting, music, electronic skills, screen printing, sewing and plywood crafts. However, for some activities it is not fully implemented because of a shortage of teaching staff or experts in work guidance.

11. Library

Room Library space in this institution, although it is quite adequate, but the condition of the books is partially outdated with the contents of the book that are not actual / not updated. This certainly influences the process of fostering child inmates, because after all children have to get actual outside world information so that they do not miss information even though they are inside the institution.

\section{Auditorium}

Room This room is intended as a multipurpose place for example to hold ceremonies, lectures, arts and so on. At present the multipurpose room is sufficiently functioned properly. For example, with more effective counseling.

13. Places of Worship

In the Makassar Penitentiary there is one prayer room and one church room. This room serves to accommodate religious activities for inmates. Physically this building is quite adequate, but it needs to be improved both qualitatively and quantitatively regarding religious programs. 


\section{Hospital}

At present the Makassar Penitentiary does not have a Special Hospital or Clinic, there is only one room that is used for medical services for child prisoners who need examination and treatment.

c. Organizational Structure

Work mechanisms, especially relations and command lines of command and staff should be able to be carried out efficiently so that the implementation of tasks in each work unit runs smoothly. Each officer must understand and be able to carry out their duties in accordance with their respective authorities and responsibilities. However, discipline and the application of organizational structures should not be tasks that are slow, but are treated flexibly as long as they do not violate existing provisions. Organizational structure is a formal pattern of activities and relationships among various subunits within the organization, and is a formal pattern of how people and jobs are grouped.

d. The Human Resources quality of human resources must be endeavored to be able to answer the challenges and problems that always exist and emerge especially within the institution. With certain qualities, it means that officers must have the minimum qualifications needed in accordance with the demands of their field of work, both those possessed in accordance with their academic abilities and the abilities obtained from the tasks obtained from experience and training. Correctional officers besides that must have the right and the same perception regarding the naughty nature of the child. Until now, only a small number of prisons have conducted special debriefing on this issue.

Based on the information from the Administration of this institution, even though the Makassar Lapas has sought to have its officers take part in exercises, leadership courses will however be inadequate in frequency, this is due to insufficient budget. In general, in dealing with these obstacles can be taken by way of working with Universities and Social Agencies to provide debriefing in the face of students in all coaching activities. In addition, a administration personnel are needed where these management personnel have a comprehensive personnel plan that covers all aspects, including; recruitment, placement, formation, transfer, education and training, career development motivation. For example upgrading programs, education and courses have something to do with career development programs. And to be able to formulate a comprehensive personnel plan must first know the scope of the task of fostering correctional students, so that it can be known the needs of employees both in quality and quantity, in this case including general administration staff, and experts such as psychologists, sociologists, community 
officers. Thus the increase of human resources in order to provide guidance for child prisoners is expected to be able to realize the idea of correcting for children. In addition, the increase in human resources is also in line with what is stated in the Beijing Rules for the Take Part. Thus in juvenile justice (in this case in particular the juvenile correctional institution) experts are needed in their field. For this reason, expertise education, training, and courses are also needed, so that guidance for child prisoners will be more meaningful. This training and education is carried out both for new employees to be able to understand and carry out the tasks assigned to them as well as for old employees to improve the quality of their duties. Basically this training and education program is implemented is a continuous process and not just a momentary process. The purpose of fostering child inmates will be achieved well if it is carried out by employees who can carry out their duties efficiently and effectively, so that human resource development is needed.

e. Management

Management is closely related to leadership quality, organizational structure and capabilities and management skills (managerial skills) from the top of the leadership and staff so that administrative management in the correctional environment as well as its relationship with the Cabruit Prison and BAPAS can run orderly and smoothly.

\section{CONCLUSION}

Limitation of criminal penalties for children is very necessary to see the facilities and infrastructure of the Makassar City penitentiary that accommodate children with problems with inadequate laws, in order to realize the ideal punishment system for children. In addition, the image of the child can be taken into consideration in the application of criminal penalties against children, because the results of this study indicate that the various concerns of the main children's parents feel embarrassed that not only children who bear the burden, but also parents of children who have problems with the law. Separation of prisoners based only on sex carried out in the form of blocks, is not an application that is in accordance with the law, which can have a detrimental effect on the obstruction of physical and psychological development of children in prisons. Erroneous perceptions of child classification not carried out by the implementing apparatus added to the severity of the system of implementing child convictions oriented to perpetrators of crimes that entered the penal institutions that did not need to be distinguished because they both contained criminals. the responsibility of the implementing apparatus seems to be lacking in legal certainty related to the implementation of unspoken concrete responsibilities related to the pattern of service and implementation of child protection in correctional institutions, 
giving rise to the impression that there is corrupt behavior that causes out of sync between legal objectives and legal functions law enforcement in the field. On the other hand, this paper also states a variety of factors that can affect the non-implementation of human rights protection for the government, including the condition and layout of buildings that do not rethink their suitability, supporting facilities and infrastructure in implementing legal protection for child prisoners, structures organization that does not work as it is ideally implemented, quality of implementing resources and implementing management.

\section{SUGGESTION}

The need to provide facilities that guarantee the needs of children in social institutions, as an effort to foster children in a sustainable and more specific way, because children are the generation of a nation that has a long future and can still be improved. Judges in making fair decisions must at least pay attention to the rights of children fundamentally, and no less important is the readiness of implementing resources and the facilities available in realizing children's rights. Implementation of guidance in the Child Correctional Institution there are factors that need attention because can function as a supporting factor and can also be a limiting factor. These factors include the following: The pattern and layout of the building as stipulated in the Decree of the Minister of Justice of the Republic of Indonesia No. M.O1.PL.01.01 In 1985 on April 11, 1985 concerning the Building Pattern of Penitentiary Institutions and State Detention Houses, it was necessary to realize this, because the pattern and layout of buildings were important factors to support the implementation of human rights for child prisoners with guidance in accordance with their objectives. correctional service.

\section{REFERENCE}

Abdullah, R. H. (2015). Urgensi Penggolongan Narapidana dalam Lembaga Pemasyarakatan. Fiat Justisia: Jurnal IImu Hukum, Universitas Lampung, 9(1), $49-60$.

Achmad, R. (2017). Hakekat Keberadaan Sanksi Pidana dan Pemidanaan dalam Sistem Hukum Pidana. Legalitas: Jurnal Hukum, Universitas Batanghari, 5(2), 79 - 104.

Aswari, A., Buana, A. P., \& Rezah, F. S. (2018). Harmonisasi Hukum Hak untuk Dilupakan bagi Koran Digital terhadap Calon Mahasiswa di Makassar. Kanun: Jurnal IImu Hukum, Universitas Syiah Kuala, 20(1), 39 - 62.

Decree of the Minister of Justice and Human Rights of the Republic of Indonesia Number M.04- HN.02.01 of 2000 concerning Additional Remission for Prisoners and Criminal Children. 
Decree of the Presidential of the Republic of Indonesia Number 50 of 1993 concerning National Human Rights Commission.

Decree of the Presidential of the Republic of Indonesia Number 174 of 1999 concerning Remission.

Dwiatmodjo, H. (2011). Pelaksanaan Perlindungan Hukum terhadap Anak yang Menjadi Korban Tindak Pidana di Wilayah Hukum Pengadilan Negeri Banyumas. Dinamika Hukum, Universitas Jenderal Soedirman, 11(2), 201 - 213.

Febriana, A. (2017). Penegakkan Hukum terhadap Anak yang Melakukan Tindak Pidana Pencabulan dalam Konsep Restorative Justice. ADIL: Jurnal Hukum, Universitas YARSI, 7(2), $202-211$.

Hilman, D. P., \& Indrawati, E. S. (2018). Pengalaman Menjadi Narapidana Remaja di Lapas Klas I Semarang. Empati, Universitas Diponegoro, 6(3), 189 - 203.

Jafar, K. (2015). Restorative Justice atas Diversi dalam Penanganan Juvenile Deliquency (Anak Berkonflik Hukum). Al-'Adl, Institut Agama Islam Negeri Kendari, 8(2), 81 $-101$.

Law of the Republic of Indonesia Number 11 of 2012 (Law No. 11 of 2012) concerning Criminal Justice System for Children. State Gazette of the Republic of Indonesia, Number 153 of 2012. Supplement to the State Gazette of the Republic of Indonesia, Number 5332.

Law of the Republic of Indonesia Number 35 of 2014 (Law No. 35 of 2014) concerning Amendment to Law No. 23 of 2002 concerning Child Protection. State Gazette of the Republic of Indonesia, Number 297 of 2014. Supplement to the State Gazette of the Republic of Indonesia, Number 5606.

Munandar, S. (2018). Pelaksanaan Perlindungan Hukum terhadap Hak Anak yang Berkonflik dengan Hukum pada Tahap Penyidikan dalam Sistem Peradilan Pidana Anak (Studi di Wilayah Hukum Polresta Padang). Pagaruyuang Law Journal, Universitas Muhammadiyah Sumatera Barat, 2(1), 42 - 63.

Nugroho, O. C. (2015). Pemenuhan Hak atas Kebutuhan Seksual Warga Binaan Pemasyarakatan. Jurnal HAM, Badan Penelitian dan Pengembangan Hukum dan HAM, 6(2), $131-146$.

Pramukti, A. S., \& Primaharsya, F. (2018). Sistem Peradilan Pidana Anak. Yogyakarta: Media Pressindo. 
Pulunggono, W., \& Chalim, M. A. (2017). Kebijakan Perlindungan Hukum terhadap Anak Korban Kekerasan dalam Rumah Tangga dengan Kontribusi Upaya Pembaharuan Hukum Pidana Nasional. Jurnal Hukum Khaira Ummah, Universitas Islam Sultan Agung, 12(2), $341-350$.

Rambitan, C. M. (2013). Tugas dan Fungsi Lembaga Pemasyarakatan dalam Merehabilitasi Anak yang Sedang Menjalani Hukuman. Lex et Societatis, Universitas Sam Ratulangi, 1(3), 67 - 76.

Rumadan, I. (2013). Problem Lembaga Pemasyarakatan di Indonesia dan Reorientasi Tujuan Pemidanaan. Jurnal Hukum dan Peradilan, Mahkamah Agung RI, 2(2), $263-276$.

Sanusi, A. (2016). Aspek Layanan Kesehatan Bagi Warga Binaan Pemasyarakatan dan Tahanan di Lembaga Pemasyarakatan dan Rumah Tahanan Negara (Aspects of Health Carestowards Convicts and Inmates). Jurnal IImiah Kebijakan Hukum, Badan Penelitian dan Pengembangan Hukum dan HAM, 10(1), 37 - 56.

Toha, S. (2009). Aspek Hukum Perlindungan terhadap Anak. Jakarta: Pusat Penelitian dan Pengembangan Hukum, Badan Pembinaan Hukum Nasional. Departemen Hukum dan HAM RI.

United Nations Emergency Children's Fund, General Assembly Resolution 44/25 of 1989 concerning Convention on the Rights of the Child.

Wahyudi, S. (2009). Penegakan Peradilan Pidana Anak dengan Pendekatan Hukum Progresif dalam Rangka Perlindungan Anak. Dinamika Hukum, Universitas Jenderal Soedirman, 9(1), 29 - 39. 